\title{
Estimation and comparison of serum lipid profile of women with pregnancy induced hypertension and normal pregnancy
}

\author{
Kapil Dev*, Rajeev Sood, Aanya Sharma
}

Department of Obstetrics and Gynecology, Kamla Nehru Hospital IGMC, Shimla, Himachal Pradesh, India

Received: 16 September 2019

Accepted: 25 October 2019

\section{*Correspondence:}

Dr. Kapil Dev,

E-mail: devkapil46@gmail.com

Copyright: (C) the author(s), publisher and licensee Medip Academy. This is an open-access article distributed under the terms of the Creative Commons Attribution Non-Commercial License, which permits unrestricted non-commercial use, distribution, and reproduction in any medium, provided the original work is properly cited.

\begin{abstract}
Background: Hypertensive disorders during pregnancy are the most common medical complication seen during pregnancy, affecting around 5-10\% of all pregnancies. Raised blood pressure in pregnancy is the major cause of fetomaternal morbidity and mortality. The most important feature in preeclampsia is hypertension which is supposed to be due to vasospastic phenomenon in kidney, uterus, placenta and brain. Altered lipid synthesis leading to decrease in PGI2:TXA2 ratio is also supposed to be an important way of pathogenesis in pregnancy induced hypertension.

Methods: This one-year prospective case control study total 200 pregnant women attending antenatal care and admitted in eclampsia ward fulfiling the inclusion criteria were studied. Serum lipid profile was estimated by semiautomatic analyzers. Statistical analysis of data was done by student's t-test and p-value.

Results: Mean total cholesterol in pregnancy induced hypertension was $278.5 \pm 52.52 \mathrm{mg} / \mathrm{dl}$ and normal pregnancy was $245.47 \pm 20.075 \mathrm{mg} / \mathrm{dl}$. Mean triglycerides in pregnancy induced hypertension was $249.88 \pm 92.575 \mathrm{mg} / \mathrm{dl} \mathrm{and}$ normal pregnancy was $206.89 \pm 46.345 \mathrm{mg} / \mathrm{dl}$. Mean HDL in pregnancy induced hypertension was $43.69 \pm 4.135 \mathrm{mg} / \mathrm{dl}$ and normal pregnancy was $49.9 \pm 6.501 \mathrm{mg} / \mathrm{dl}$. Mean LDL in pregnancy induced hypertension was $174.43 \pm 39.083 \mathrm{mg} /$ $\mathrm{dl}$ and normal pregnancy was $151.22 \pm 19.92 \mathrm{mg} / \mathrm{dl}$. Mean VLDL in pregnancy induced hypertension was $46.885 \pm 15.143 \mathrm{mg} / \mathrm{dl}$ and in normal pregnancy was $40.964 \pm 9.061 \mathrm{mg} / \mathrm{dl}$, total cholesterol, low density lipoprotein, very low density lipoprotein, triglycerides were increased in pregnancy induced hypertension when compared to normal pregnancy, which is statistically significant.

Conclusions: We concluded that the Patient who developed pre-eclampsia have abnormal lipid profile. This abnormal lipid profile is responsible for endothelial dysfunction. This endothelial dysfunction may play a key role the pathophysiology of pre-eclampsia. Early detection of these parameters may help patient by preventing complications and is going to aid in better management of pre-eclampsia.
\end{abstract}

Keywords: Pregnancy induced hypertension, Pre-eclampsia and eclampsia, Serum lipid profile

\section{INTRODUCTION}

Hypertensive disorders during pregnancy are the most common medical complication seen during pregnancy, affecting around $5-10 \%$ of all pregnancies. ${ }^{1}$ Raised blood pressure in pregnancy is the major cause of fetomaternal morbidity and mortality. ${ }^{2}$ The association of altered lipid profile in essential hypertension is well documented. ${ }^{3}$
One important theory of preeclampsia is oxidative stress and abnormal lipid profiles may have role in promotion of oxidative stress and vascular dysfunction. ${ }^{4}$ An abnormal lipid profile is strongly associated with atherosclerotic cardiovascular disease and has a direct effect on endothelial dysfunction. ${ }^{5}$ During pregnancy, the increased level of estrogen causes increased hepatic biosynthesis of endogenous triglycerides through VLDL, 
this process is modulated by hyperinsulinism that starts in pregnancy and may result in endothelial cell damage in pregnancy. ${ }^{6}$ There is 2-3 times rise in serum triglyceride concentration which are likely to get accumulated in the uterine spiral arteries contributing to endothelial activation and damage. ${ }^{7}$ The most important feature in preeclampsia is hypertension which is supposed to be due to vasospastic phenomenon in kidney, uterus, placenta and brain. Altered lipid synthesis leading to decrease in PGI2:TXA2 ratio is also supposed to be an important way of pathogenesis in pregnancy induced hypertension. ${ }^{8}$ Compared to normal pregnancies, in preeclampsia endocrinological alterations are more, in turn there will be change in serum lipids among preeclampsia. ${ }^{9}$ Obviously the association of serum lipid profile with gestational proteinuric hypertension is highly suggested to reflect some new diagnostic tools. ${ }^{10}$

This study was conducted to investigate and compare the serum lipid levels in women with pregnancy induced hypertension and normal pregnancy in the department of obstetrics and gynecology, Kamla Nehru Hospital for mother and Child, IGMC Shimla.

Objective of this study was estimation and comparison of serum lipid profile of women with pregnancy induced hypertension and normal pregnancy.

\section{METHODS}

The present study was a prospective case control study done from July 2016 to July 2017 and included two hundred pregnant women attending antenatal care and admitted in eclampsia ward at Kamla Nehru State Hospital for Mother and Child, attached to Indira Gandhi Medical College, Shimla. A total of two hundred patients were evaluated in this study after obtaining a written informed consent. Women at POG>22 weeks were included a hundred hypertensive women as case group and control group include another hundred normotensive women after matching the gestation age. Women with chronic hypertension, cardiovascular disorder, renal disease, twin pregnancy, molar pregnancy, chromosomally abnormal fetus, diabetes, auto immune disorder, thrombophilia, family history of diabetes mellitus and cardiovascular disease were excluded from the study. Detailed history was taken according to proforma. A thorough general physical examination, systemic examination, obstetric examination and pelvic examination was done. Various investigations included complete hemogram, platelet count, liver function tests, renal function tests, coagulation profile, fundus examination and 24-hour quantitative estimation of urine protein. Serum lipid profile was estimated by semiautomatic analyzers. Obstetric management was done according to standard protocol existing in the department. Anticonvulsant and anti-hypertensive drugs were given according to standard protocol. Details of labour whether induced or spontaneous labour, progress of labour and mode of delivery was noted.

\section{Statistical analysis}

Statistical analysis of data was done by student's t-test and p-value.

\section{RESULTS}

In our study 89 patients (45\%) were between the age group of 25 to 30 years among which 49 patients $(55 \%)$ had PIH and rest had normal BP and where around 31 patients $(16 \%)$ were above 30 years, in this age slab 18 patients $(58 \%)$ had high BP while rest were normotensive and the $\mathrm{p}$ value was found to be non-significant.

Table 1: Distribution of the patient according to age and demographic profile.

\begin{tabular}{|llllll|}
\hline Age in year & PIH $(\mathbf{N}=100)$ & $\%$ & Normotensive $(\mathbf{N}=100)$ & $\%$ & p value \\
\hline$<20$ years & 4 & $67 \%$ & 2 & $33 \%$ & 0.678 \\
\hline $20-25$ years & 29 & $39 \%$ & 45 & $61 \%$ & 0.028 \\
\hline $25-30$ years & 49 & $55 \%$ & 40 & $45 \%$ & 0.255 \\
\hline$>30$ years & 18 & $58 \%$ & 13 & $42 \%$ & 0.434 \\
\hline Demographic characteristics & PIH & $\%$ & Normotensive & $\%$ & p value \\
\hline Rural & 63 & $63 \%$ & 52 & $52 \%$ & 0.152 \\
\hline Urban & 37 & $37 \%$ & 48 & $48 \%$ & 0.152 \\
\hline
\end{tabular}

Table 2: Distribution of patients according to socioeconomic status.

\begin{tabular}{|llllll|}
\hline SES & PIH $(\mathbf{N}=100)$ & $\%$ & Normotensive $(\mathbf{N}=100)$ & $\%$ & p value \\
\hline Upper, upper middle & 11 & $11 \%$ & 30 & $30 \%$ & 0.002 \\
\hline Lower middle & 28 & $28 \%$ & 48 & $48 \%$ & 0.005 \\
\hline Upper lower & 44 & $44 \%$ & 17 & $17 \%$ & $<0.001$ \\
\hline Lower & 17 & $17 \%$ & 5 & $5 \%$ & 0.013 \\
\hline
\end{tabular}


Majority of the patients both in the hypertensive and normotensive group belonged to rural areas around 62\% $(\mathrm{n}=62)$ and $52 \%(\mathrm{n}=52)$ respectively (Table 1$)$.

In the table shown above it was observed that out of 100 patient who had pregnancy induced hypertension, 11 patients $(11 \%)$ of them belonged to upper, upper middle class. Around 28 patients $(28 \%)$ of patient belonged to lower middle class and around 17 patients (17\%) belonged to lower class (Table 2).
Out of 100 normotensive patients observed in this study, it was found that 30 patients $(30 \%)$ belonged to upper, upper middle class, 48 patients $(48 \%)$ belonged to lower middle class, 17 patients $(17 \%)$ belonged to upper lower class $(\mathrm{p}$ value $=<0.001)$ and 5 patients $(5 \%)$ belonged to lower class $(\mathrm{p}$ value $=0.013)$. Which was statistically significant. It was observed that PIH was more prevalent in upper lower and lower class of socioeconomic status.

Table 3: Comparison of $\mathrm{BMI}\left(\mathrm{Kg} / \mathrm{m}^{2}\right)$ between PIH and normotensive.

\begin{tabular}{|c|c|c|c|c|c|}
\hline & PIH & & Normotensive & & p value \\
\hline & Mean & STDEV & Mean & STDEV & \\
\hline $\mathrm{BMI}\left(\mathrm{Kg} / \mathrm{m}^{2}\right)$ & 23.826 & 1.914 & 22.915 & 1.903 & 0.954 \\
\hline
\end{tabular}

Considering the body mass index of the patients, it was concluded that a mean BMI of the patients categorized as pregnancy induced hypertension was $23.826 \mathrm{~kg} / \mathrm{m}^{2}$ with standard deviation of 1.914 while the mean BMI of the patients categorized as normotensive was $22.915 \mathrm{~kg} / \mathrm{m}^{2}$ with standard deviation of 1.903 (Table 3).

It was concluded that the $\mathrm{p}$ value of above comparison was 0.954 which was statistically insignificant.

Table 4: Distribution of patient according to period of gestation.

\begin{tabular}{|llllllll|}
\hline $\begin{array}{l}\text { Gestation age } \\
\text { in week }\end{array}$ & $\begin{array}{l}\text { No. of patients } \\
(\mathbf{N}=200)\end{array}$ & $\%$ & $\begin{array}{l}\text { PIH } \\
(\mathbf{N}=100)\end{array}$ & $\%$ & $\begin{array}{l}\text { Normotensive } \\
(\mathbf{N}=100)\end{array}$ & $\%$ & p value \\
\hline$<32$ weeks & 18 & $9 \%$ & 10 & $55.5 \%$ & 8 & $44.5 \%$ & 0.805 \\
\hline $32-34$ weeks & 38 & $19 \%$ & 21 & $55.2 \%$ & 17 & $44.8 \%$ & 0.589 \\
\hline $34-37$ weeks & 114 & $57 \%$ & 59 & $51.7 \%$ & 55 & $48.3 \%$ & 0.668 \\
\hline$>37$ weeks & 30 & $15 \%$ & 10 & $33.3 \%$ & 20 & $66.7 \%$ & 0.073 \\
\hline
\end{tabular}

As shown in the above table 10 patients $(55.5 \%)$ having the gestational age below 32 weeks belongs to PIH (p $=0.805)$. Around 21 patients $(55.2 \%)$ between the gestational age of 32 to 34 weeks had high blood pressure $(\mathrm{p}=0.589)$. A total of 59 patients out of 114 patients $(51.7 \%)$ between the gestational age of 34 to 37 weeks had higher blood pressure and above the gestational age of > 37 weeks only10 patients $(33.3 \%)$ had high blood pressure $(\mathrm{p}=0.073)$ (Table 4).
It was observed that around 100 patients $(50 \%)$ had a systolic blood pressure less than $140 \mathrm{mmHg}$ and belonged to normotensive group. Around 58 women (29\%) had systolic BP ranging between 140 to $150 \mathrm{~mm}$ $\mathrm{Hg}$ while 32 women (16\%) had systolic BP ranging between 151 to $160 \mathrm{mmHg}$ and only 10 women $(5 \%)$ had systolic above $160 \mathrm{mmHg}$ and belonged to $\mathrm{PIH}$ group (Table 5).

Table 5: Distribution of patients as per systolic blood pressure (SBP).

\begin{tabular}{|llllllll|}
\hline SBP mmHg & $\begin{array}{l}\text { No. of patients } \\
(\mathbf{N}=200)\end{array}$ & $\%$ & $\begin{array}{l}\text { PIH } \\
(\mathbf{N}=100)\end{array}$ & $\%$ & $\begin{array}{l}\text { Normotensive } \\
(\mathbf{N}=100)\end{array}$ & $\%$ & p value \\
\hline$<140$ & 100 & $50 \%$ & 0 & $0 \%$ & 100 & $100 \%$ & $<0.001$ \\
\hline $140-150$ & 58 & $29 \%$ & 58 & $100 \%$ & 0 & $0 \%$ & $<0.001$ \\
\hline $151-160$ & 32 & $16 \%$ & 32 & $100 \%$ & 0 & $0 \%$ & $<0.001$ \\
\hline$>160$ & 10 & $5 \%$ & 10 & $100 \%$ & 0 & $0 \%$ & 0.003 \\
\hline
\end{tabular}


Table 6: Distribution of patients according to diastolic blood pressure (DBP).

\begin{tabular}{|lll|lllll|}
\hline DBP mmHg & $\begin{array}{l}\text { No. of patients } \\
(\mathbf{N}=200)\end{array}$ & $\%$ & $\begin{array}{l}\text { PIH } \\
(\mathbf{N}=100)\end{array}$ & $\%$ & $\begin{array}{l}\text { Normotensive } \\
(\mathbf{N}=100)\end{array}$ & $\%$ & p value \\
\hline$<90$ & 100 & $50 \%$ & 0 & $0 \%$ & 100 & $100 \%$ & $<0.001$ \\
\hline $90-100$ & 80 & $40 \%$ & 80 & $100 \%$ & 0 & $0 \%$ & $<0.001$ \\
\hline $100-110$ & 10 & $5 \%$ & 10 & $100 \%$ & 0 & $0 \%$ & 0.003 \\
\hline$>110$ & 10 & $5 \%$ & 10 & $100 \%$ & 0 & $0 \%$ & 0.003 \\
\hline
\end{tabular}

Table 7: Comparison of total cholesterol levels in normotensive and pregnancy induced hypertension.

\begin{tabular}{|llllll|}
\hline & PIH & \multicolumn{5}{c|}{ Normotensive } & STDEV & p value \\
\hline Total CHO $\mathrm{mg} / \mathrm{dl}$ & Mean & STDEV & Mean & 20.07584 & $<0.0005$ \\
\hline
\end{tabular}

It was observed that around 50\% (100 patients) had diastolic blood pressure below $90 \mathrm{mmHg}$. Around 80 women (40\% women) had systolic BP ranging between 90 to $100 \mathrm{~mm} \mathrm{Hg}$ while 10 women ( $5 \%$ women) had diastolic BP ranging between 100 to $110 \mathrm{mmHg}$ an only 10 women (5\% women) had diastolic above $110 \mathrm{mmHg}$ (Table 6).
In the table above it is shown that the mean cholesterol levels in pregnancy induced hypertensive patients was found to be $278.5 \mathrm{mg} / \mathrm{dl}$ with standard deviation of 52.52 while the mean cholesterol levels in Normotensive patients was found to $245.47 \mathrm{mg} / \mathrm{dl}$ with standard deviation of 20.07584 and was found to be statistically significant with $\mathrm{p}$ value of less than 0.0005 (Table 7).

Table 8: Comparison of triglyceride levels in normotensive and pregnancy induced hypertension.

\begin{tabular}{|llllll|}
\hline & PIH & & Normotensive & & \\
\hline & Mean & STDV & Mean & STDV & p value \\
\hline TRIG mg/dl & 249.88 & 92.57553 & 206.89 & 46.34497 & $<0.0005$ \\
\hline
\end{tabular}

The mean triglycerides levels in pregnancy induced hypertensive patients was found to be $249.88 \mathrm{mg} / \mathrm{dl}$ with standard deviation of 92.57553 whole the triglycerides levels in Normotensive patients was found to be 206.89 $\mathrm{mg} / \mathrm{dl}$ with standard deviation of 46.34497 . The $\mathrm{p}$ value for the above correlation was $<0.0005$ and was statistically significant (Table 8).
In the table below it was observed that the mean value of HDL levels in pregnancy induced hypertensive patients was $43.69 \mathrm{mg} / \mathrm{dl}$ with standard deviation of 4.135813 and the mean value of HDL levels in Normotensive patients was found to be $49.9 \mathrm{mg} / \mathrm{dl}$ with standard deviation of 6.501748 and the above values were found to be statistically significant with $\mathrm{p}$ value of less than 0.0005 (Table 9).

Table 9: Comparison of mean HDL levels in normotensive and pregnancy induced hypertension.

\begin{tabular}{|llllll|}
\hline & PIH & & Normotensive & & \\
& Mean & STDV & Mean & STDV & p value \\
\hline HDL $\mathrm{mg} / \mathrm{dl}$ & 43.69 & 4.135813 & 49.9 & 6.501748 & $<0.0005$ \\
\hline
\end{tabular}

In the table below it was observed that the mean value of LDL levels in pregnancy induced hypertensive patients was $174.43 \mathrm{mg} / \mathrm{dl}$ with standard deviation of 39.08378 and the mean value of LDL levels in normotensive patients was found to be $151.22 \mathrm{mg} / \mathrm{dl}$ with standard deviation of 19.92135 and the above values were found to be statistically significant with $p$ value of less than 0.0005 (Table 10).
In the table below it was observed that the mean value of VLDL levels in pregnancy induced hypertensive patients was $46.888 \mathrm{mg} / \mathrm{dl}$ with standard deviation of 15.14307 and the mean value of VLDL levels in Normotensive patients was found to be $40.964 \mathrm{mg} / \mathrm{dl}$ with standard deviation of 9.061468 and the above values were found to be statistically significant with $p$ value of less than 0.0005 (Table 11). 
Table 10: Comparison of mean LDL levels in normotensive and pregnancy induced hypertension.

\begin{tabular}{|llllll|}
\hline & PIH & & Normotensive & & \\
\hline & Mean & STDEV & Mean & STDEV & p value \\
\hline LDL $\mathrm{mg} / \mathrm{dl}$ & 174.43 & 39.08378 & 151.22 & 19.92135 & $<0.0005$ \\
\hline
\end{tabular}

Table 11: Comparison of mean VLDL levels in normotensive and pregnancy induced hypertension.

\begin{tabular}{|lll|lll|}
\hline & PIH & & Normotensive & & \\
\hline & Mean & STDV & Mean & STDV & p value \\
\hline VLDL $\mathrm{mg} / \mathrm{dl}$ & 46.885 & 15.14307 & 40.964 & 9.061468 & $<0.0005$ \\
\hline
\end{tabular}

Table 12: Lipid profile in pregnancy induced hypertension.

\begin{tabular}{|lllllll|}
\hline & Gest HIT & & PRE-ECL & & ECL \\
\hline & Mean & STDV & Mean & STDV & Mean & STDV \\
\hline TRIG mg/dl & 232.18 & 77.22 & 299.37 & 107.65 & 293.88 & 133.94 \\
\hline Total CHO mg/dl & 274.52 & 47.48 & 291.68 & 62.34 & 284.00 & 71.88 \\
\hline HDL $\mathrm{mg} / \mathrm{dl}$ & 43.66 & 3.78 & 44.84 & 5.67 & 41.25 & 1.39 \\
\hline LDL $\mathrm{mg} / \mathrm{dl}$ & 178.41 & 39.71 & 175.47 & 33.35 & 135.63 & 42.53 \\
\hline VLDL $\mathrm{mg} / \mathrm{dl}$ & 45.26 & 14.52 & 53.11 & 14.06 & 46.98 & 18.19 \\
\hline
\end{tabular}

As shown in the table above when the comparison between the mean values of components of lipid profile was done it was seen that in patients with gestational hypertension the mean triglycerides was $232.18 \mathrm{mg} / \mathrm{dl}$ with standard deviation of 77.22, mean total cholesterol was $274.52 \mathrm{mg} / \mathrm{dl}$ with standard deviation of 47.48, mean HDL was $43.66 \mathrm{mg} / \mathrm{dl}$ with standard deviation of 3.78 , mean LDL was $178.41 \mathrm{mg} / \mathrm{dl}$ with standard deviation of 39.71, mean VLDL was $45.26 \mathrm{mg} / \mathrm{dl}$ with standard deviation of 14.52 (Table 12).

Similarly in patients with eclampsia the mean triglycerides was $293.88 \mathrm{mg} / \mathrm{dl}$ with standard deviation of 133.94, mean total cholesterol was $284.00 \mathrm{mg} / \mathrm{dl}$ with standard deviation of 71.88 , mean HDL was $41.25 \mathrm{mg} / \mathrm{dl}$ with standard deviation of 1.35 , mean LDL was 135.63 $\mathrm{mg} / \mathrm{dl}$ with standard deviation of 42.53 , mean VLDL was $46.98 \mathrm{mg} / \mathrm{dl}$ with standard deviation of 18.19 .

Similarly, in patients with preeclampsia the mean triglycerides was $299.37 \mathrm{mg} / \mathrm{dl}$ with standard deviation of 107.65, mean total cholesterol was $291.68 \mathrm{mg} / \mathrm{dl}$ with standard deviation of 65.34, mean HDL was $44.84 \mathrm{mg} / \mathrm{dl}$ with standard deviation of 5.67 , mean LDL was $175.47 \mathrm{mg} / \mathrm{dl}$ with standard deviation of 33.35 , mean VLDL was $53.11 \mathrm{mg} / \mathrm{dl}$ with standard deviation of 14.06 .

\section{DISCUSSION}

Pregnancy induced hypertension including preeclampsia, are important factors of severe morbidity, disability and death among mothers, fetus and infants. Management of preeclampsia aims to minimalist any pregnancy related complications, avoiding unnecessary prematurity and maximize maternal and perinatal survival.
In this study a simple screening was investigated to decrease the complications related to preeclampsia, detection of serum lipid profile in early pregnancy decreases the risk of preeclampsia.

In our present study it was found that the mean age of the pregnancy induced hypertensive patients was $27.1 \pm 4.073$ year which was comparatively more than the mean age of normotensive patients and this comparison was found to be statistically insignificant. On the contrary the other studies like Shivanagappa $M$ et al, showed that the mean age of PIH patients was $25.44 \pm 3.5$ year which was not found to be significant. ${ }^{11}$ Similarly, in the study conducted by Khatun $\mathbf{J}$ et al, concluded that the mean age of the pregnancy induced hypertensive patients was $25.12 \pm 3.98$ year which was found to be statistically insignificant. $^{12}$

In our study the mean BMI of normotensive patient was $22.91 \pm 1.9 \mathrm{Kg} / \mathrm{m}^{2}$ and in $\mathrm{PIH}$ was $23.082 \pm 1.91 \mathrm{Kg} / \mathrm{m}^{2}$ and the difference was statically insignificant with $\mathrm{p}$ value 0.958. However, it was in contrast with some other studies. In the study conducted by Shivanagappa $\mathrm{M}$ et al, mean BMI of normotensive patient was 21.63 \pm 2.19 $\mathrm{Kg} / \mathrm{m}^{2}$ and in $\mathrm{PIH}$ was $21.52 \pm 1.51 \mathrm{Kg} / \mathrm{m}^{2}$ where the difference was statistically insignificant. ${ }^{11}$ In the study conducted by Khatun J, Amir S, mean BMI of normotensive patient was $21.43 \pm 2.09 \mathrm{Kg} / \mathrm{m}^{2}$ and in $\mathrm{PIH}$ was $22.02 \pm 1.73 \mathrm{Kg} / \mathrm{m}^{2}$ and the difference was statistically insignificant. $^{12}$

In our study mean systolic blood pressure in normotensive group was $116.48 \pm 5.96$ and in PIH group was $150.74 \pm 7.35$ and difference between the cases and controls was found to be significant with $\mathrm{p}$ value $<0.001$. 
Similar to the study conducted by Khatun $\mathrm{J}$ et al, where the mean systolic blood pressure in Normotensive Group was $115.1 \pm 9.39 \mathrm{mmHg}$ and in PIH group was $163.7 \pm 11.24 \mathrm{mmHg}$ and difference was also significant with $\mathrm{p}$ value $<0.001 .{ }^{12}$

Similarly, in the study conducted by Yadav S et al, mean systolic blood pressure in normotensive group was $120.8 \pm 2.74 \mathrm{mmHg}$ and in PIH group was $153.2 \pm 16.14$ $\mathrm{mmHg}$ and difference were significant with $\mathrm{p}$ value $<0.001 .^{13}$

In our study mean diastolic blood pressure in normotensive group was $74.76 \pm 5.23 \mathrm{mmHg}$ and in $\mathrm{PIH}$ group was $97 \pm 6.7 \mathrm{mmHg}$ and difference were significant with $\mathrm{p}$ value $<0.001$. And the above findings were profoundly supported by the other studies conducted in the similar prospect. In the study conducted by Khatun J et al, mean diastolic blood pressure in normotensive group was $71.5 \pm 5.41 \mathrm{mmHg}$ and in PIH group was $100.6 \pm 5.41 \mathrm{mmHg}$ and difference were significant with $\mathrm{p}$ value $<0.001 .^{12}$ In the study conducted by Yadav $\mathrm{S}$ et al, mean Diastolic blood pressure in Normotensive group was $74.32 \pm 2.21 \mathrm{mmHg}$ and in $\mathrm{PIH}$ group was $103.0 \pm 10.351 \mathrm{mmHg}$ and difference was significant with $\mathrm{p}$ value $<0.001 .^{13}$

There was a marked rise in the total cholesterol levels of patients with preeclampsia in our study in comparison to the control group. The total cholesterol in normotensive group was $245.47 \pm 20.07 \mathrm{mg} / \mathrm{dl}$ and in PIH group was $278.5 \pm 52.52 \mathrm{mg} / \mathrm{dl}$ and difference were significant statistically with $\mathrm{p}$ value $<0.0005$. The rise in cholesterol level could be considered as an important indicator for the changes in the lipid profile in pre-eclampsia patients. Even the other studies conducted there was a significant rise in the total cholesterol levels.

In the study conducted by Shivanagappa $M$ et al, total cholesterol in normotensive group was $172.95 \pm 40.74$ $\mathrm{mg} / \mathrm{dl}$ and in PIH group was $259.91 \pm 76.61 \mathrm{mg} / \mathrm{dl}$ and difference were statistically significant with $p$ value $<0.001{ }^{11}$ In the study conducted by Khatun $\mathrm{J}$ et al, total cholesterol in normotensive group was $194.56 \pm 43.33$ $\mathrm{mg} / \mathrm{dl}$ and in PIH group was $227.56 \pm 55.79 \mathrm{mg} / \mathrm{dl}$ and difference was statistically significant with $\mathrm{p}$ value $<0.001 .^{12}$

In the study conducted by Yadav $\mathrm{S}$ et al, total cholesterol in normotensive group was $143.33 \pm 25.24 \mathrm{mg} / \mathrm{dl}$ and in $\mathrm{PIH}$ group was $242.38 \pm 52.03 \mathrm{mg} / \mathrm{dl}$ and difference were statistically significant with $\mathrm{p}$ value $<0.001 .^{13}$

In the study conducted by Shahu S et al, Total cholesterol in normotensive group was $172.1 \pm 9.3 \mathrm{mg} / \mathrm{dl}$ and in PIH group was $293.3 \pm 15.7 \mathrm{mg} / \mathrm{dl}$ and difference were statistically significant with p value $<0.001 .{ }^{14}$

There was significant rise in the triglycerides levels in pre-eclampsia as compared to normal pregnancy in our study, which was similar to other reports. In our present study the mean value of triglyceride in PIH group was $249.88 \pm 92.57 \mathrm{mg} / \mathrm{dl}$ and in normotensive group was $206.89 \pm 46.34 \mathrm{mg} / \mathrm{dl}$ difference was statistically significant with $\mathrm{p}$ value $<0.0005$.

Similarly, in the study conducted by Shivanagappa $M$ et al, mean value of triglyceride in PIH group was $275.38 \pm 12.32 \mathrm{mg} / \mathrm{dl}$ and in normotensive group was $152.84 \pm 48.63 \mathrm{mg} / \mathrm{dl}$ and the difference were statistically significant with $\mathrm{p}$ value $<0.001{ }^{11}$ Similarly, in the study conducted by Khatun $\mathrm{J}$ et al, mean value of triglyceride in PIH group was $232.06 \pm 65.54 \mathrm{mg} / \mathrm{dl}$ and in normotensive group was $158.44 \pm 64.26 \mathrm{mg} / \mathrm{dl}$ difference being statistically significant, with $\mathrm{p}$ value $<0.001 .{ }^{12}$

In the study conducted by Yadav $\mathrm{S}$ et al, mean value of triglyceride in PIH group was $281.96 \pm 99.84 \mathrm{mg} / \mathrm{dl}$ and in normotensive group was $124.48 \pm 18.67 \mathrm{mg} / \mathrm{dl}$ and the difference were statistically significant with $p$ value $<0.001 .^{13}$

In the study conducted by Shahu $\mathrm{S}$ et al, mean value of triglyceride in PIH group was $233.57 \pm 34.6 \mathrm{mg} / \mathrm{dl}$ and in normotensive group was $86.7 \pm 10.8 \mathrm{mg} / \mathrm{dl}$ and the difference were statistically significant with $p$ value $<0.001$. $^{14}$

All these studies were comparable to present study.

In our study there was a significant fall in HDL in preeclampsia cases. It was found that estrogen is responsible for induction of triglycerides and HDL but in pregnancy induced hypertension there is a marked fall in estrogen levels as compared to normotensive group, therefore hypoestrogenism and insulin resistance in preeclampsia could lead to decreased HDL level. In our study the mean value of HDL in PIH group was $43.69 \pm 4.13 \mathrm{mg} / \mathrm{dl}$ and in normotensive group was $49.9 \pm 6.50 \mathrm{mg} / \mathrm{dl}$, mean value of $\mathrm{HDL}$ in PIH was lower than normotensive.

Studies conducted by Shivanagappa $\mathrm{M}$ et al, Khatun $\mathrm{J}$ et al, and Shahu $\mathrm{S}$ et al, were comparable to the present study. ${ }^{11,12,14}$

In our study it was seen that the mean LDL levels were markedly raised $174.43 \pm 39.08 \mathrm{mg} / \mathrm{dl}$ in comparison to the LDL levels of normotensive patients. The LDL levels were also calculated in other studies. Shivanagappa M et al, found that there was significant increase in the LDL levels of $\mathrm{PIH}$ patients $154.68 \pm 47.98 \mathrm{mg} / \mathrm{dl}$ in comparison to the normotensive patients with LDL levels of $88.44 \pm 30.47 \mathrm{mg} / \mathrm{dl}$ and it was statistically significant. ${ }^{11}$

In another study conducted by Khatun $\mathrm{J}$ et al, also concluded in their study that the LDL levels were $147.72 \pm 51.03$ in pregnancy induced hypertensive patients and the $\mathrm{p}$ value was less than 0.001 , which was statistically significant. ${ }^{12}$ Shahu $\mathrm{S}$ et al, also concluded in their study that LDL levels were $196.7 \pm 15.3 \mathrm{mg} / \mathrm{dl}$ in 
pregnancy induced hypertensive patients and they were even markedly raised and the $p$ value was less than $0.001 .{ }^{14}$ And supporting the conclusion of our study.

There was significant rise in the VLDL levels in preeclampsia as compared to normal pregnancy in our study, which was similar to other reports. In our present study the mean value of VLDL in PIH group was $46.88 \pm 15.14 \mathrm{mg} / \mathrm{dl}$ and in normotensive group was $40.96 \pm 9.06 \mathrm{mg} / \mathrm{dl}$ difference was statistically significant with $\mathrm{p}$ value $<0.0005$.

Similarly, in the study conducted by Shivanagappa $\mathrm{M}$ et al, mean value of VLDL in PIH group was $65.00 \pm 26.73 \mathrm{mg} / \mathrm{dl}$ and in normotensive group was $28.76 \pm 11.38 \mathrm{mg} / \mathrm{dl}$ difference was statistically significant with $\mathrm{p}$ value $<0.001 .{ }^{11}$

In the study conducted by Shahu $\mathrm{S}$ et al, mean value of VLDL in PIH group was $46.7 \pm 6.9 \mathrm{mg} / \mathrm{dl}$ and in normotensive group was $17.3 \pm 2.2 \mathrm{mg} / \mathrm{dl}$ difference was statistically significant with $\mathrm{p}$ value $<0.001 .{ }^{14}$

In the study conducted by Gawande MS et al, mean value of VLDL in PIH group was $13.19 \pm 2.06 \mathrm{mg} / \mathrm{dl}$ and in normotensive group was $12.03 \pm 1.901 \mathrm{mg} / \mathrm{dl}$ difference was statistically significant with $\mathrm{p}$ value $<0.001 .^{15}$

All these studies were comparable to the present study.

\section{CONCLUSION}

Authors concluded that the patient who developed preeclampsia have abnormal lipid profile. This abnormal lipid profile is responsible for endothelial dysfunction. This endothelial dysfunction may play a key role the pathophysiology of pre-eclampsia. Early detection of these parameters may help patient by preventing complications and is going to aid in better management of pre-eclampsia.

\section{Funding: No funding sources}

Conflict of interest: None declared

Ethical approval: The study was approved by the Institutional Ethics Committee

\section{REFERENCES}

1. Mallick MP, Ray S, Medhi R, Bisai S. Eleveted serum beta hCG and dyslipidimia in second trimester as predictor of subsequent pregnancy induced hypertension. Bangladesh Med Res Counc Bull. 2014;40:97-101.

2. Modi DA, Rami BD, Wander GK. Role of serum $\beta$ hcg and lipid profile in early second trimester as predictors of hypertensive disorders of pregnancy. Int J Res Med. 2015;4(4):34-7.
3. Phalak P, Tilak M. Study of lipid profile in Preeclampsia. Indian J Bas Appl Med Res. 2012;5(2):405-9.

4. Saha D, Roy P, Pal R. Serum lipid profile- how it alter in normotensive and hypertensive pregnant women. $\mathrm{J}$ Evolut Med Dent Sci. 2013;2(31):5895-902.

5. Kiran Y, Shalini A, Kamlesh V. Serum bhCG and lipid profile in early second trimester as predictors of pregnancy-induced hypertension. The $\mathrm{J}$ Obstet Gynecol India. 2014;64(3):169-74.

6. Nayan S, Meena ML, Hooja N, Fatima A, Singh N, Aseri S. A study of comparison of serum lipid profile of women with pregnancy induced hypertension and normal pregnancy. Sch Acad J Biosci. 2014;2(11):834-6.

7. Singh A, Khambra P, Rani KU, Mandal AK. Assessment of serum $\beta$ hCG, lipid profile and uric acid levels in early second trimester as predictors of pregnancy induced hypertension. Ann Pathol Laborat Med. 2016;3(3):157-61.

8. Kalar MU, Kalar N, Mansoor F, Malik AR, Lessley $\mathrm{T}$, Kreimer S, et al. Preeclampsia and lipid levels - a case control study. Int J Collaborat Res Inter Med Pub Health. 2012;4(10):1738-45.

9. Anuradha R, Durga T. Estimation of lipid profile among preeclampsia woman by comparing with normal pregnancy. Int $\mathbf{J}$ Contemp Med Res. 2016;3(7):1958-61.

10. De J, Mukhopadhyay AK, Saha PK. Study of serum lipid profile in pregnancy induced hypertension. Indian J Clin Boichem. 2006;21(2):722-7.

11. Shivanagappa M, Singh S, Sujatha MS, Mahadevaih M. Comparative study of lipid profile in normotensive and hypertensive pregnant women. Inte J Sci Stu. 2015;3(7):222-5.

12. Khatun J, Amir S. In the pre-eclampsia and normotensive patient- lipid profile study. Med Today. 2017;29(2):1-3.

13. Yadav S, Shrivastav N, Paneri S, Pawar P. The study of beta hCG level along with general biochemical profile in pre-eclampsia. IOSR J Dent Med Sci. 2014;13(7):28-1.

14. Sahu S, Abraham R, Vedavalli R, Daniel M. Study of lipid profile, lipid peroxidation and vitamin e in pregnancy induced hypertension. Indian J Physiol Pharmacol. 2009;53(4):365-9.

15. Gawande MS, Joshi SA. Lipid profile in patients of pre-eclampsia: a comparative study. Panacara J Med Sci. 2016;6(3):155-8.

Cite this article as: Dev K, Sood R, Sharma A.

Estimation and comparison of serum lipid profile of women with pregnancy induced hypertension and Normal Pregnancy. Int J Reprod Contracept Obstet Gynecol 2019;8:4939-45. 